Журнал «Герспективитаінноваціїнауки»

(Серія«Гедагогіка»), Серія«ГТихологія», Серія «Медицина»

№5(5) 2021

UDC: $378.147 .091 .21: 378.811: 316.624 .2(045)$

https://doi.org/10.52058/2786-4952 -2021-5(5)-48-57

Hrachova Inna Volodymyrivna Ph.D. in Philology, Senior Researcher, Senior Scientific Officer, Department of Research and Organization, National Academy of the National Guard of Ukraine, Zakhysnykiv Ukrainy sq., 3, Kharkiv, Ukraine, 61000, tel.: 050-403-1983, e-mail: innagrachovav@ gmail.com, http//orcid.org/00000002-4022-1719

Nikonenko Oleh Viktorovych Senior Assistant of the Chief, Department of Research and Organization, National Academy of the National Guard of Ukraine, Zakhysnykiv Ukrainy sq., 3, Kharkiv, Ukraine, 61000, e-mail: nikon2999@ukr.net, http//orcid.org/0000-0003-0689-2030

Kupriienko Yuliia Ihorivna Assistant Chief, Department of Research and Organization, National Academy of the National Guard of Ukraine, Zakhysnykiv Ukrainy sq., 3, Kharkiv, Ukraine, 61000, http//orcid.org/0000-0002-7450-3263, e-mail: yliakuprienko@gmail.com

\title{
DEALING WITH BEHAVIOURAL PROBLEMS AND THE WAYS OF THEIR SOLVING WHILE TEACHING FOREIGN LANGUAGES IN HIGHER MILITARY EDUCATIONAL ESTABLISHMENTS
}

Abstract. The paper investigates students' behavioural problem in higher educational establishments and aims to find appropriate ways of its solution. The purpose of the research is to investigate some samples of students' difficult behaviour and find the ways how to deal with it. In the article the references devoted to the topic of difficult students' behaviour have been analyzed. The research covers mostly the practical side of this issue. For that purpose empirical methods of research have been used: experiments, observational methods. Nowadays students are considered to be difficult and have deviant behaviour and consequently must be punished for that. The idea of our approach is that teachers can not solve the problem with the help of punishment. For the research a range of experiments has been conducted. As the experience shows the punishment does not improve the situation even worsens. So the only way to solve the problem is to treat these students with respect as people but with some peculiarities in their behaviour. It can be concluded that the following methods of dealing with difficult behaviour are efficient: to make students think in a responsible way, use sense of humour and respect in complicated situations, cooperate with students as close as possible, provide them choice even for their punishment, allow behaviour that can not be stopped, gradually assign responsibility and leadership, display a personal concern every day, value every student equally, not label students as 'good' or 'bad' ones, emphasize that you do not 
like student's misbehavior, not them. For the punishment and rewards teacher must find the balance between rewards and sanctions, trying to persuade them to "get better than you were yesterday", praise students when they study and behave well, focusing on the effort and the strategy they used.

Keywords: behavioural problems, challenging students, conduct, deviant behaviour, difficult students, educational process, society.

Грачова Інна Володимирівна кандидат філологічних наук, старший дослідник, старший науковий співробітник науково-організаційного відділу, Національна академія Національної гвардії України, майдан Захисників України, 3, м. Харків, 61000, e-mail: innagrachovav@gmail.com, https://orcid.org/0000-0002-4022-1719

Ніконенко Олег Вікторович старший помічник начальника науковоорганізаційного відділу Національна академія Національної гвардії України, майдан Захисників України, 3, м. Харків, 61000, e-mail: nikon2999@ukr.net, https://orcid.org/0000-0003-0689-2030

Купрієнко Юлія Ігорівна помічник начальника науково-організаційного відділу, Національна академія Національної гвардії України, майдан Захисників України, 3, м. Харків, 61000, https://orcid.org/0000-0002-7450-3263, e-mail: yliakuprienko@gmail.com

\section{ПОВЕДІНКОВІ ПРОБЛЕМИ ТА ШЛЯХИ ЇХ РІШЕННЯ ПРИ ВИКЛАДАННІ ІНОЗЕМНИХ МОВ У ВИЩИХ ВІЙСЬКОВИХ НАВЧАЛЬНИХ ЗАКЛАДАХ}

Анотація. У статті розглядається проблема поведінкових проблем студентів у вищих навчальних закладах. Ми не можемо виключити складних студентів із навчального процесу, тому викладачі повинні ефективно працювати $з$ ними. Отже, метою статті є дослідити деякі зразки складної поведінки студентів у вищих навчальних закладах та знайти шляхи боротьби 3 нею. У статті проаналізовано джерела літератури, присвячені темі складної поведінки студентів. Дослідження присвячене практичній стороні цієї проблеми. Для цього були використані емпіричні методи дослідження: експерименти, методи спостереження. В українській освітній системі студенти зі складною поведнікою вважаються девіантними i, отже, за це повинні бути покарані. Ідея нашого підходу полягає в тому, що покарання - це не вирішення проблеми. Для дослідження було проведено ряд експериментів. Як показує досвід, покарання не покращує ситуацію, а навіть іï погіршує. Тож єдиний спосіб вирішити проблему - налагодити добрі відносини з цими студентами та відноситися 3 повагою до них як до решти членів групи, але 3 певними особливостями в їхній поведінці. Можна прийти до висновку, що наступні 
методи роботи із девіантною поведінкою є найбільш ефективними: навчити студентів мислити відповідально, використовувати почуття гумору, поважати студентів навіть у складних ситуаціях, тісно співпрацювати зі студентами, давати можливість обирати покарання для себе, дозволяти проявляти поведінку, яку неможливо зупинити, демонструвати особисту зацікавленість кожного дня, відноситися до всіх студентів однаково, не розділяти студентів на «поганих» та «гарних», наголошувати на тому, що вам не подобається саме їхні поведінка, а не особистість. Щодо покарань і заохочень викладач має знайти баланс, намагаючись переконати їх бути сьогодні кращими ніж учора, заохочувати студентів, коли вони вчаться та поводяться добре, фокусуючись на їх зусиллях.

Ключові слова: девіантна поведінка, навчальний процес, поведінка, поведінкові проблеми, складні студенти, суспільство.

Formulation of the problem. In higher educational establishments while dealing with groups of students teachers encounter with students' difficult behaviour. Students disobey teachers and authorities in general, do not respect their group mates. Definitely these students can not be excluded from the group and educational process. But what can be done and how should teachers react to such conduct? Challenging beheviour of students is increasingly recognized as a serious, worldwide public concern. In order to solve the problem of difficult behaviour, it is necessary to investigate what the difficult/ deviant conduct is and examine various definitions of this term. Recent theoretical developments have revealed that deviant behavior is an unacceptable behavior or action that is appropriate for social and cultural norms. "An individual with this behavior deviates from what is truly acceptable in the society or what is expected in a normal pattern" [1]. "A specific standard behavior is called norms in which people are supposed to act in a predictable manner. Deviant behavior is a violation of this norm although it can be interpreted in many ways as social norms are different from one culture to another" [1]. Kowalski [2] states that difficult behaviour or "classroom incivilities" can include: lateness or leaving early, inappropriate cellphone and laptop usage in class, side conversations, disregard for deadlines, grade grubbing, sniping remarks, cheating. They can cause consequences such as: "distracting other students and instructor in class, reducing student participation, lowering other students' and instructor's motivation in or out of class, affecting fairness in grading, feeling disrespected as a fellow learner or authority figure" [2].

In order to deal successfully with such students it is necessary to look into the real reasons for their conduct. Among the main causes of "difficult" students" behaviour Sally L. Kuhlenschmidt and Lois E. Layne [3] consider: physical ones (using drugs, medication, illnesses, fatigue, discomfort, vision and hearing problems), emotional challenges (loss, maturity, attention seeking, redirected aggression), environmental factors (norms for conduct, class size, culture, task, routine and stimulation). Scientists state that deviant actions can have different 
functions and purposes and sometimes are used by people in order to assert their individuality and identity to show themselves as personalities. Behaving deviantly people can rebel against society norms. Analysing the literature devoted to the topic of the students' behavioural problems mostly theoretical articles describing classifications of types and reasons of deviant conduct have been found. In publications this type of students' conduct is mostly called "difficult" or "challenging" and only the most inadequate acts to social norms - "deviant". A number of authors have made an attempt to find the tips and rules to help teachers deal with the problem. But it must be admitted that in spite of some useful tips mentioned in these articles that mostly deal with secondary school pupils there are not any real examples of students' misbehaviour and appropriate ways out. Moreover, the rules used abroad do not always suit the Ukrainian reality so it is necessary the experience of foreign methodologists to be adjusted to the higher educational system in Ukraine.

Consequently, the purpose of the article is to investigate some samples of students' difficult behaviour in higher military educational establishments, find the ways dealing with it. For that purpose empirical methods such as experiments, observational methods have been used in the research. Taking into account the experience of the predecessors it can be concluded that the reasons of deviant/difficult behaviour can be more serious that they seem. So if the reasons of students ' deviant behaviour are known it is easier to find the ways for solving this social problem, keeping in mind that they have internal conflict between the traits of character which do not conform to the rules of the society.

Analysis of recent research and publications. A large number of alternative approaches have been developed over the last few decades. So in order to find the ways of solving the problem of deviant behaviour the main approaches have been reviewed. Dr. Allen Mendler, an American scientist, educator and creator of the Discipline with Dignity method of classroom management in his article suggests that for dealing with difficult students teachers must "grow closer" to them - "somehow, some way, form a relationship" [4].

But sometimes even such measures do not help while dealing with "difficult" students. In some cases these students are uncontrollable in the educational process. They disobey teachers and behave in an eccentric way: they talk aloud with group mates, walk across the class without permission, do not do the tasks suggested by the teacher. Furthermore they can chat in social networks, take pictures or make video clips with other students and the teacher, use illiterate words.

As a base of experiments of the study the 'Discipline with Dignity' approach developed by Dr. Richard Curwin and Dr. Mendler has been taken. According to it responsible thinking, sense of humour, cooperation, providing choices, allowing behaviour that can not be stopped, mutual respect, and shared decision making are the steps for improving students` behaviour.

Similarly, in Chapter Dealing with Challenging Students in Educator's Guide to Preventing and Solving Discipline Problems Boynton mentions the following tips for 
teachers: "gradually assign responsibility and leadership, display a personal interest daily, value the student, despite the inappropriate action, provide the student with choices" [5].

Shalaway's methods have been used while conducting the experiments: to identify the reasons of behaviour; be positive when dealing with difficult students; speak to a student about his or her behaviour in private; "focus on recognizing and rewarding acceptable behavior"; do not label students as 'good' or 'bad' ones; teach students academic, personal and social skills; listen to the students attentively, underline that you do not like student's misbehavior, not them [6]. Another important finding was that "the balance between rewards and sanctions, in both policy and practice, is a useful touchstone of a school's approach to maintaining good standards of behaviour. Where schools lay the emphasis on rewards the best results are found" [7].

For the research several experiments have been held. The first part of experiments is devoted to students` behavioural problems concerning discipline. For this purpose two students of different groups (age of 17-18) with difficult behaviour have been selected. Both groups have problems with discipline, atmosphere and the level of knowledge of English (E). Permanent noise and talks during double periods are destroying basic conditions for sufficient learning. Teachers are nervous and desperate while having lessons with these groups. The second part of experiments deals with a group of cadets (aged 19 to 23) who are in frustrated and depressed psychological state. The third part of experiments has been conducted to determine what ways of punishment and rewards are the most effective.

Results and Discussions. Part 1. Experiment 1. Assigning leadership. Different types of strategies and methods have been used to deal with student A. There have been three steps: aggressive measures, friendly measures, constructive measures. Step 1. While cheating during the test Student A. was told that his work was not be accepted. Nevertheless he continued cheating and at the end of the lesson he brought the work to the teacher. When the work was not accepted he left the classroom without saying anything. From that moment he started behaving in even more disrespectful way ignoring the teacher $(\mathrm{PhD}$, the head of department). In order to solve the problem the teacher turned to the dean's office. The dean talked to the student about his behaviour but it did not give any results. Then the other ways to solve this problem were suggested: moving him to another group, trying to expel him from a dormitory where he lived, gathering some negative facts about his actions. He refused to attend another group and became even more eccentric. Despite all the mentioned steps the student's behaviour did not change.

Step 2. The decision to talk to him personally as a friend was made. He told the teacher about his parents and grandparents who were highly-educated people but tried to limit him as a personality. It could be concluded that he wanted to show that he was an adult person and consequently be treated like to a grown-up. It was an icebreaking moment. But in the class there was still the same problem - he talked and misbehaved.

Step 3. Then drastic measures were taken: he was suggested being a teacher in a 
group. He sat next to the teacher at the teacher's desk, read the tasks instead of the teacher, corrected mistakes which were made by the group mates, gave marks at the end of the lesson. He was slightly corrected and lead by the teacher but in general he was given as much freedom to act as it was possible. The reaction of the group was quite positive. They were excited with this experiment. It was the first lesson in this group which was quiet, really controlled. Analysing what had happened the conclusion was made that with his «deviate» behaviour he was trying to make people respect and accept him as an adult person. Since then there were no problems any longer. He could be asked to help the teacher and he did it with pleasure and respect.

Experiment 2. Giving responsibilities. Student D. behaved in even more eccentric way. Once he ate his test paper, he spoilt group mates' glasses for tea degustation task and tried to smoke in a class. Threatening and speeches were useless. It was obvious that with the help of his misbehaviour he was trying to attract attention to his personality. Nevertheless despite his "challenging" actions he was always ready to help the teacher. So the decision was made to involve him in charity activity for an orphanage that needed help. He organized a group of friends to help. Being there he was seen in a different way as a positive person eager to help, who dealt with children so easily and positively. His eccentric way of behaviour disappeared, he behaved correctly and tactfully. At the end of the event he was shown respect and was thanked for the help. Since that time the atmosphere in the class has improved. The teacher paid attention to his positive traits without avoiding the negative ones, but treated them as normal for this very person. It must be admitted that at the end of a year he had a real progress in studying and behaving.

Part 2. One more problem that we can encounter with in the teaching process is students' passive conduct and depressive state. Dr. Mendler notes that teachers "need to be more demonstrative in showing the caring that is in our hearts. Make it a top goal to be a cheerleader for your students, particularly those students whose actions make others want to turn away from them" [4].

Experiment 3. In military establishments there are the groups of cadets who are demotivated, frustrated and even depressed. It is known that there is the biggest number of suicides among soldiers that's why teachers must be very attentive to the "alarm signals". At the lessons teachers often hear the cadets' thoughts that life is hard and senseless. Cadets participate in class work without any enthusiasm. Dr. Mendler focuses that "watching 'difficult' students pursue knowledge that interests them is an exciting, dynamic experience. The idea of learning being 'fun' may be a new concept for them. Help them grow their 'learning is fun' muscle while also helping them understanding there are different 'kinds' of fun as well' [4].

While teaching English teachers can use various grammar games, creative tasks which motivate cadets to speak, imagine situations, create some stories. Not serious topics can make cadets feel even more relaxed. It is important to make them study but it is more crucial to be their elder friend to make them study more effectively.

Once while checking the home task - to write a scary story - various quite expected stories about ghosts, devil, witches, Grim Reapers were heard. One cadet 
read his story which wasn't actually a story. He wrote down his anxious depressive maniac thoughts about his hatred towards people and his will to kill everybody. Everyone in the group who heard that story was alarmed. It was a signal for the teacher for analyzing his behaviour in progress during the year.

The usefulness of social networks while dealing with such problems must be admitted. In his profile the last posts were rather destructive even rude though the previous ones were friendly and peaceful pictures with his family. Teachers who had classes with his group admitted his depressive state and one of them remembered he was talking about some problems with his family. It was obvious that he was getting through hard times. So there were several ways to follow. Firstly to report about some suggestions to the officers, secondly, leave it all as it is, thirdly, talk to him personally. The last variant was chosen.

The teacher spoke to the cadet saying that he was worrying about his psychological state. He was astonished. He said that it was the first person who really took care about it. He confessed that he was having some problems but he assured that he had enough courage to deal with them and thanked for the concern. Some days after that he asked the teacher to read the book of his poetry. He turned out to be a thoughtful young man-philosopher with deep thoughts and ideas. After personal communication his mood changed, he started smiling and being friendlier. Later the officers who were responsible for this group said that he had been having troubles with his father. So it can be admitted that personal touch while dealing with difficult behaviour is efficient.

Part 3. In the research there have been several experiments concerning rewards and punishment. Teachers have got used to putting marks so much that often miss an opportunity to talk with students about their success and failures. But if you do not praise and comment on students' every more or less significant achievements they will not know whether they are making progress or not. "Get your kids to understand that "getting better than you were yesterday" is the daily standard of success. Great teachers make it between hard and impossible for their students to fail: "Don't ever expect me to give up on you and never give up on yourself." Praise them when they do well, with your focus being on the effort and the strategy they used", according to Dr. Mendler`s theory [4].

Experiment 5 . The first-year cadet started studying in the academy with a very low level of knowledge of English, but she worked hard, asked questions if she did not understand anything. She was progressing continuously. As the reward it was chosen her efforts to be praised and the officers to be informed about her success in her presence. It was the best reward for her and as a result she tried her best. Her entrance level was low satisfactory mark (E), in a half of a year she made progress up to a good mark (C).

Experiment 6. A five-year cadet was completely silent at the beginning of the year. When he was asked a question he did not say a word, just smiled. During the first test he was sitting doing nothing. The teacher came up to him and tried to help. He was encouraged to do the first task. He did it. Then he did all the tasks correctly 
by himself even better than his group mates did it. The teacher expressed admiration about the cadet's success. After this he started studying, did home tasks, participated in class work, he tried to answer my questions and asked his questions about grammar and translation of the words, asked for some additional tasks and grammar books, worked at the blackboard with enthusiasm. It was noticed that he could learn spelling of words quite easily and wrote word dictations well. He started progressing gradually, always being praised for all his more or less successful work.

Experiment 7. For the experiment we used creative kinds of punishment that can improve the situation, save a good image of a teacher, encourage students to be broadminded and help them learn English. For example, a student does not do the home task. Of course teachers can give a long speech how badly he has acted and how important home task is or can just put a bad mark. But is not it the easiest and the most useless means of punishment? Thus it was offered to the students to choose different variants of punishment for them: for example, learning a poem (e.g. "To be or not to be"), making a video where they explain some grammar rules, doing dozen of additional exercises, putting an unsatisfactory mark in the register or just telling their officers about breaking the discipline. Teachers must be democratic and flexible even in these aspects. So when a cadet asked to write his own poem and learn it instead of learning a proposed one, he was allowed doing it and did it perfectly. Another cadet was so inspired that offered to help him make the rhyme better. Besides the cadets who chose to make video clips showed much creativity and inspiration as well. It is proved that punishment can be joyful and pleasant if it is creative and democratic.

Conclusion. Summing up the results of the experiments, it can be concluded that all aggressive steps that were taken to solve students` behavioural problems were useless, moreover they made the situation worse. The only way to improve it is to take democratic measures and respect every student in the class.

Difficult economical and psychological conditions have influence on the youth in the destructive way. Teachers must remember that they do not only teach, but also bring up, help, look into the students' personality. In classroom teachers also play the role of psychologists, tutors, mentors and elder friends. Teachers often encounter with insufficient students' psychological state and can not avoid this serious problem nowadays. Difficult students in our educational system are the "odd men out". It is considered that they have deviant conduct and consequently must be punished for that. The idea of the approach is that punishment is not the solving of the problem. As the experience shows that the punishment does not improve the situation at all even makes it worse. So the only way to solve the problem is to encourage students/cadets to help teachers and treat them as normal people but with some peculiarities in their behaviour. Only paying maximum attention to their positive sides and traits of character such as responsibility, kindness, intelligence, charisma, etc. we can achieve our educational goal - to help a student develop into a welleducated person and a well-qualified specialist. Students can study well they just require a particular individual approach though it needs much time, patience and 
efforts. Although teachers must be positive, notice and emphasize all the positive aspects of the learning process of every student, some restrictions and punishment for breaking important rules can not be avoided.

Summing up we can conclude that the following methods of dealing with difficult behaviour are efficient: to make students think in a responsible way, use sense of humour and respect in complicated situations, cooperate with students as close as possible, provide them choice even for their punishment, allow behaviour that can not be stopped, gradually assign responsibility and leadership, display a personal concern every day, value every student equally, not label students as 'good' or 'bad' ones, emphasize that you do not like student's misbehavior, not them. For the punishment and rewards teacher must find the balance between rewards and sanctions, trying to persuade them to "get better than you were yesterday", praise students when they study and behave well, focusing on the effort and the strategy they used. Further research of the topic can be connected with the development of new progressive methods for dealing with deviant behaviour in higher military educational establishments under the conditions of emergency or the martial law.

\section{References:}

1. Vitaro, F., Brendgen M., Larose S., Tremblay R.E. Kindergarten disruptive behaviors, protective factors, and educational achievement by early adolescence. Journal of Educational Psychology. 2005; 97: 617-629. [in English].

2. Kowalski, R. M. (2003) Address Problematic Student Behavior. Retrieved from https://www.cmu.edu/teaching/designteach/teach/problemstudent.html. [in English].

3. Kuhlenschmidt, Sally L., Layne, Lois E. Strategies for Dealing with Difficult Behavior (n.d.) Retrieved March 03, 2021, from https://www.uow.edu.au/content/groups/public/@web/ @ stsv/@swd/documents/doc/uow068340.pdf. [in English].

4. Mendler, A. 6 Strategies For Dealing With 'Difficult' Students. (n.d.) Retrieved April 06, 2018, from https://www.teachthought.com/pedagogy/growing-closer-to-your-most-challengingstudents/. [in English].

5. Boynton, M., Boynton, Ch. Dealing with Challenging Students. [Educator's Guide to Preventing and Solving Discipline Problems]. (n.d.) Retrieved May 23, 2021, from http://www.ascd.org/ publications/books/105124/chapters/Dealing-with-Challenging-Students.aspx. [in English].

6. Shalaway, L. 25 Sure-Fire Strategies for Handling Difficult Students. Learning to Teach...Not Just for Beginners: The Essential Guide for All Teachers. (n.d.) Retrieved April 08, 2018, from https://www.scholastic.com/teachers/articles/teaching-content/25-sure-fire-strategieshandling-difficult-students/. [in English].

7. Irish National Teachers` Organisation. Managing Challenging Behaviour Guidelines for Teachers. (n.d.) Retrieved February 21, 2021, from https://www.into.ie/ROI/Publications/ ManagingChallengingBehaviour.pdf. [in English].

8. Dix P. 10 tips for teachers in managing pupil behaviour. (n.d.) Retrieved March 12, 2021, from https://www.theguardian.com/society/joepublic/2010/feb/09/pupil-behaviour-management-tips [in English].

9. Linsin, M. The 7 Rules Of Handling Difficult Students. (n.d.) Retrieved March 24, 2021, from https://www.smartclassroommanagement.com/2011/04/23/7-rules-of-handling-difficult-students/. [in English].

10. Ponomarenkova, Ye., Rabiga, V. Kenzhebekovab, I., Aidarbek, Yessaliyevc, A., Kulahmet, Moldabekb et al. Pedagogical Research Methods of Training in Higher Educational 
Establishments: A Comparative Analysis IEJME //Mathematics Education, Vol. 11, NO. 9, 2016, 3221-3232. [in English].

11. Wali Rahman Nasib Dar, Two angles of overqualification-the deviant behavior and creative performance: The role of career and survival job. Retrieved April 08, 2021, from https://journals.plos.org/plosone/article?id=10.1371/journal.pone.0226677\# [in English]. 